\title{
The Valiant Welshman, the Scottish James, and the Formation of Great Britain
}


RESEARCH IN MEDIEVAL AND EARLY MODERN CULTURE STUDIES IN MEDIEVAL AND EARLY MODERN CULTURE

Medieval Institute Publications is a program of The Medieval Institute, College of Arts and Sciences 


\section{The Valiant Welshman, the Scottish James, and the Formation of Great Britain}

Megan S. Lloyd

Research in Medieval and Early Modern Culture

Studies in Medieval and Early Modern Culture

MEDIEVAL INSTITUTE PUBLICATIONS

Western Michigan University

Kalamazoo 
Copyright (C) 2018 Walter de Gruyter GmbH, Berlin/Boston

\section{Library of Congress Cataloging-in-Publication Data}

Names: Lloyd, Megan S., 1963- author. | Armin, Robert, active 1610.

Title: The Valiant Welshman, the Scottish James, and the formation of Great

Britain / Megan S. Lloyd.

Description: Kalamazoo : Medieval Institute Publications, Western Michigan

University, [2018] | Series: Research in medieval and early modern culture

| Includes bibliographical references and index.

Identifiers: LCCN 2018050136 (print) | LCCN 2019000641 (ebook) | ISBN

9781580443548 (pdf) | ISBN 9781580443531 (hardcover : alk. paper) | ISBN 9781580443548 (ebook)

Subjects: LCSH: Valiant Welshman (Drama) | Politics and literature--Great

Britain--History--17th century. | Wales--In literature. | England--In

literature. | Politics in literature. | Kings and rulers in literature. |

James I, King of England, 1566-1625.

Classification: LCC PR2411 (ebook) | LCC PR2411 .V433 2018 (print) | DDC

$822 / .3-$ dc23

LC record available at https://lccn.loc.gov/2018050136

ISBN: 9781580443531

eISBN: 9781580443548

All rights reserved. Without limiting the rights under copyright reserved above, no part of this book may be reproduced, stored in, or introduced into a retrieval system, or transmitted, in any form, or by any means (electronic, mechanical, photocopying, recording or otherwise) without the written permission of both the copyright owner and the author of the book.

Every effort has been made to obtain permission to use all copyrighted illustrations reproduced in this book. Nonetheless, whosoever believes to have rights to this material is advised to contact the publisher. 